\title{
The Study on the Impact of Tourism Prices on International Tourism Demand: The Case of Chinese Inbound Tourism from 15 Tourist Markets
}

\author{
Zhang Qiong
}

\begin{abstract}
The study aims to quantitatively examine how tourism prices affect tourism demand using data of tourists travelling to China from 17 country origins. Based on quarterly data from 1996 to 2016 , we employ econometric approaches to investigate how economic and noneconomic factors, including real GDP per capita, income, tourism prices, transportation costs, economy openness and exogenous adverse events, relate to tourism demand. In particular, to study the effect of tourism price on tourism demand for China, we construct six different price variables in our empirical analysis. The results indicate that relative price standardized by exchange rate is the best proxy for tourism price, while transportation cost is not statistically significant. We also find that external shocks caused by medical disease and financial crisis have a significant impact on the demand for Chinese international tourism.
\end{abstract}

Index Terms-International tourism, tourism prices, econometric approaches, demand models.

\section{INTRODUCTION}

With the advancing of globalization and economic integration, international tourism has achieved remarkable development during the past decades. As one of the leading forces in the world economy, international tourism represents $10 \%$ of the world's GDP and greatly contributes to the creation of jobs and infrastructure. The number of international tourists increased from 25 million in 1950 to 1.23 billion in 2016, while international tourism receipts surged from $\$ 2$ billion to $\$ 1.22$ trillion [1].

Academic researchers have conducted extensive studies on the international tourism. Numbers of studies has been devoted to identify key determinants of international tourism demand [2]. For instance, reference [3] conducted an overview of determinants of tourism demand and the methodologies employed during the period of 1961-1993. Reference [4] identified 121 research papers of international tourism demand during the period 2000-2007.

By reviewing the extant literature, we found that the determinants of international tourism demand are country-specific and the performance of the those forecasting models varies from country to country. Meanwhile, the different forms of the tourism price also

Manuscript received March 2, 2019; revised May 1, 2019.

Zhang Qiong is with School of Tourism, Sichuan University, Chengdu, China (e-mail: olivia.zhangq@stu.scu.edu.cn). pose a big challenge, which lead to the inconsistent results in tourism demand research [5]. Accordingly, the purpose of this study is to identify the appropriate price factors of the tourism demand for China.

\section{LITERATURE REVIEW}

In general, researchers model tourism demand employing following proxies: tourist arrivals, tourism expenditure, and tourism receipts. The most commonly used proxy is tourist arrivals which could be divided further into holiday tourist arrivals, business tourist arrivals, tourist arrivals for visiting friends and relatives (VFR) purposes [6]. Although the use of those proxies is theoretically reasonable, their estimating performance is probably different from case to case. Reference [7] compares tourist arrivals and tourist expenditures in the context of econometric modeling and forecasting of the tourism demand for Hongkong, which reveals that the forecasting performance of tourism expenditure is better than tourist arrivals. Also, they maintain that the choice of demand measure is based on the objective of analysis.

In the tourism literature, tourism demand is a function of several economic and non-economic variables. One of the widely used independent variables is income in origin countries, which acts a part either as a source or as a result of tourism demand. According to the demand theory, the relationship between income and tourism demand is positive, that is, the increment of the income is expected to boost the demand for tourism. In general, researchers use gross domestic production or gross national product per capita as a proxy for income [8].

Tourism price is another important determinant of tourism demand. Based on the classical economic theory, a fall in tourism price would lead to an increase in tourism demand. Tourism price is comprised of two parts: living cost and transportation cost [9]. There are typically two components of living cost:(1)the prices of products and tourism service in destination country, such as accommodation [8], food and beverage prices, and local transportation cost [10], and(2)the exchange rates of destination country. According to reference [4], the living cost of tourism price can be classified as relative price (RP) and substitute price (SP), and both prices indicators are important to tourism demand. Normally, in the econometric studies of tourism demand, at least one of those price variables is included into the specific construction of the 
tourism price. Often, the information about the price level of products and tourism service cannot be acquired in advance, therefore, researchers tend to use relative consumer price index (CPI) as a proxy for price level [11], [12].

Exchange rate is another indicator of living cost, which has been a dominant determinant of tourism demand [13]. The relationship between the exchange rate and tourism demand is negative, indicating that an appreciation of a destination's currency would frustrate the inbound tourist flows. However, researchers hold different views about the inclusion of exchange rate and relative prices in tourism demand model. Some researchers include exchange rate alone in the model on the grounds that most international tourists are more likely to be aware of the changes in exchange rate rather than price level in destination country. Reference [14] argued that inclusion of both variables may cause misspecification because exchange rate is also a measure of relative prices which could be offset by exchange rate. Reference [15] concluded that the exchange rate and a relative price proxy should not be examined in tourism demand model separately, but rather the inclusion of relative prices adjusted by exchange rate as an effective price variable is reasonable [16].

Transportation cost represents a significant factor in international tourism demand. Reference [17] revealed that distance discourage tourism demand between destinations and tourist origins. In the existing literature, no completely favorable index exists in the context of international transportation cost due to the complexities of the price structure. Normally, geographic distance has been widely used as a proxy to estimate the international tourism demand for a destination on the basis of the gravity model. Some researchers use oil price and jet fuel price as proxy for transport cost.

Trade openness, albeit rarely, has been investigated in the estimation of tourism demand models. Reference [18] concluded that there was a bilateral causal relationship between international trade and international tourism in the context of China. Reference [19] examined the causal relationship between the openness and tourism demand for Singapore, and arrived at the same conclusion

There are several non-economic variables should be considered in tourism demand model. An autoregressive term, also known as lagged dependent variable [20], is an important variable should be included in the model to capture tourist's habit persistence and the effect of word-of-mouth. The intention of this variable is to explain the extent the tourists spread the information from destination country to others after they return to the origin country, which may influence potential customer's decision-making behavior [21].

Dummy variables were used to analyze the effect of seasonal changes and exogenous shocks which may exert negative impact on international tourism demand.

\section{Methodology Model}

The sample is based on the quarterly tourist arrivals from 15 countries to China during the period of 1996 to 2016. According to the inconsistent use of tourism price in literature, we formulate 6 tourism demand models with different price variables, and a double log-linear function was used, which allow researchers to examine the elasticity. The tourism demand function is expressed as follows:

$$
\begin{aligned}
& T D_{i t}= \\
& A * I N C M_{i t}^{\beta_{1}} R P_{i t}^{\beta_{2}} S P_{i t}^{\beta_{3}} E X R_{i t}^{\beta_{4}} \operatorname{TRC}_{i t}^{\beta_{5}} \mathrm{HOP}_{i t}^{\beta_{6}} \mathrm{FOP}_{i t}^{\beta_{7}} * \varepsilon_{i t}
\end{aligned}
$$

where the letter $t$ denote time, $i$ denote country origin, and the variables introduced are defined as:

$T D_{i t}=$ total number of tourists from country $i$ at time $t$;

$I N C M_{i t}=$ real GDP per capita of country $i$ at time $t$;

$R P_{i t}=$ relative price calculated as:

$\left(C P I_{i t} / C P I_{\text {China }, t}\right)$

$E R P_{i t}=$ effective relative price calculated as:

$\left\{\left[\left(C P I_{i t} / C P I_{\text {China }, t}\right)\right] *\left[1 /\right.\right.$ Exchange rate $\left.\left._{i t}\right]\right\}$, where $C P I_{i t}$ is the consumer price index at country $i$ at time $t$, Exchange Rate ${ }_{i t}$ is the bilateral exchange rate between

China and country $i$ at time $t$;

$S P_{i t}=$ effective price calculated as :

$\left(C P I_{\text {China }, t} / C P I_{\text {Competing destinations }, t}\right)$

$E S P_{i t}=$ effective substitute price calculated as:

$\left\{\left[C P I_{\text {China,t }} / \text { (Weighted CPI }\right)_{\text {Competing destinations, } t}\right] *$

$\left[1 /\right.$ Exchange rate $\left.\left._{i t}\right]\right\}$, where $C P I_{\text {Competing destinations }, t}$ is the consumer price index at competing countries at time $t$, Exchange Rate ${ }_{i t}$ is the bilateral exchange rate between China and country $i$ at time $t$; and South Korea, Japan, Singapore and Taiwan China were selected as competing destinations for China, and they were equally weighted in the model estimation;

$T R C_{i t}=$ Jet fuel price $t *$ Distance $_{\mathrm{i}}$, and Jet fuel price $\mathrm{t}_{\mathrm{t}}$ is the jet fuel price per gallon at time $t$ in dollars, and Distance $\mathrm{i}_{\mathrm{i}}$ denotes the distance between China and country $i$;

$$
\begin{aligned}
& F O P_{i t}=\left[\left(\text { Imported goods }_{i, t}+\text { Exported goods }_{i, t}\right) /\right. \\
& \left.\left(G D P_{i t}\right)\right]^{*} 100 \% \\
& \text { HOP }_{\text {China }, t}= \\
& {\left[\left(\text { Imported goods }_{\text {China }, t}+\text { Exported goods }_{\text {China }, t}\right) /\right.}
\end{aligned}
$$

$\left.\left(\mathrm{GDP}_{\text {China }, t}\right)\right] * 100 \%$, where $F O P_{i t}$ is the total volume of imports and exports relative to the GDP of country $i$ at time $t$, and $\mathrm{HOP}_{\text {China, } t}$ is the total volume of imports and exports divide the GDP of China at time $t$;

Q2, Q3, Q4= seasonal dummies for the second, third and fourth quarter of the year;

$D M_{1}=$ the SARS in 2003;

$D M_{2}=$ the financial crisis broke in the third quarter of 2008 .

\section{DATA SOURCE}

This empirical study includes 15 major international markets: Korea, Japan, USA, Russia, Malaysia, Philippines, Singapore, Canada, Australia, Thailand, German, UK, France, Italy, and New Zealand, to China using quarterly observations from 1999 to 2016.

The data about the inbound tourist numbers was collected from the website of China National Tourism Administration, and the data of GDPs was obtained from OECD and IMF. The CPIs (the base year is 2010) and exchange rates are from the IMF Statistical Database. The jet fuel prices were 
from the US EIA Energy Information Administration, and the geographic distance was retrieved from CEPII. The CPIs, exchange rate, import goods and export goods are from IMF statistics database, and the GDP data was obtained from OECD. The CPI for Taiwan China is from Statistical yearbook of the republic of China 2017.

\section{EMPIRICAL RESULTS}

To avoid spurious regression problems, the data must be modeled in a suitable econometric framework. Accordingly, prior to panel data analysis, the test for unit roots is necessary to check the stationarity of the variables. We examine the stochastic properties of the data mainly by the LLC test developed by Levin Lin Chu (2002) and the IPS test developed by Pesaran and Shin Im (2002). Both of them have the null hypothesis of a unit root.

\begin{tabular}{|c|c|c|c|c|}
\hline \multirow{2}{*}{$\begin{array}{l}\text { Test } \\
\text { Variable }\end{array}$} & \multicolumn{2}{|l|}{ LLC } & \multicolumn{2}{|l|}{ IPS } \\
\hline & T statistic & P-value & T statistic & P-value \\
\hline $\mathrm{TA}$ & -5.29 & $(0.000)$ & 41.75 & $(0.169)$ \\
\hline INCM & -1.39 & $(0.08)$ & 17.59 & $(0.99)$ \\
\hline $\mathrm{RP}$ & -3.487 & $(0.002)$ & 42.27 & $(0.156)$ \\
\hline SP & 7.077 & (1.000) & 1.331 & (1.000) \\
\hline EXR & -0.264 & $(0.396)$ & 33.69 & $(0.483)$ \\
\hline ERP & 1.464 & (0.928) & 22.883 & (0.926) \\
\hline ESP & 1.812 & $(0.965)$ & 14.138 & (0.998) \\
\hline HOP & -4.053 & $(0.001)$ & 74.62 & $(0.001)$ \\
\hline FOP & -3.361 & $(0.004) * *$ & 70.065 & $(0.003) * *$ \\
\hline TRC & -4.1025 & $(0.001)$ & 42.213 & $(0.157)$ \\
\hline$\Delta \mathrm{TA}$ & $-22.59 * * *$ & $(0.000)$ & $474.15^{* * *}$ & $(0.000)$ \\
\hline$\triangle \mathrm{INCM}$ & $-11.89^{* * *}$ & $(0.000)$ & $286.09^{* * *}$ & $(0.000)$ \\
\hline$\Delta \mathrm{RP}$ & $-11.562 * * *$ & $(0.000)$ & $394.52 * * *$ & $(0.000)$ \\
\hline$\Delta \mathrm{SP}$ & $-15.326 * * *$ & (0.000) & $487.01 * * *$ & $(0.000)$ \\
\hline$\Delta \mathrm{EXR}$ & $-11.03 * * *$ & $(0.000)$ & $245.4 * * *$ & $(0.000)$ \\
\hline$\triangle \mathrm{ERP}$ & $-12.273 * * *$ & $(0.000)$ & $259.546 * * *$ & $(0.000)$ \\
\hline$\Delta \mathrm{ESP}$ & $-13.01^{* * *}$ & $(0.000)$ & $267.11 * * *$ & $(0.000)$ \\
\hline$\Delta \mathrm{HOP}$ & $-25.82 * * *$ & $(0.000)$ & $313.15^{* * *}$ & $(0.000)$ \\
\hline$\Delta \mathrm{FOP}$ & $-14.958 * * *$ & $(0.000)$ & $439.646 * * *$ & $(0.000)$ \\
\hline$\Delta \mathrm{TRC}$ & $-15.123 * * *$ & $(0.000)$ & $293.98 * * *$ & $(0.000)$ \\
\hline
\end{tabular}

Notes : (1) All variables are in natural logarithmic form. (2) $\Delta$ is first difference operator. (3) ***, **,*indicate $1 \%, 5 \%$ and $10 \%$ significance, respectively.

Table I illustrates the results of unit root test. According to the results, the tests do not reject the null hypothesis of a unit root. In other words, the variables are not stationary at the $1 \%$ confidence level. However, all variables are stationary after taking the first order difference.

\begin{tabular}{ccc} 
& TABLE II: COINTEGRATION TEST RESULTS \\
\hline Statistic & Test statistic & p-value \\
\hline Panel v-Statistic & 1.9865 & 0.0234 \\
Panel rho-Statistic & -11.688 & 0.0000 \\
Panel PP-Statistic & -13.8618 & 0.0000 \\
Panel ADF-Statistic & -14.895 & 0.0000 \\
Group rho-Statistic & -9.9894 & 0.0000 \\
Group PP-Statistic & -14.265 & 0.0000 \\
Group ADF-Statistic & -14.556 & 0.0000 \\
\hline
\end{tabular}

Table II demonstrates the Johansen test of the null hypothesis of no cointegration, and the results indicate the presence of the long-run cointegration relationship in the model. Therefore, international tourism demand for China converges to it long-run equilibrium by correcting any possible deviation from this equilibrium in the short-run. Once the cointegration is determined, the long-run parameters of the independent variables could be estimated. 
TABLE III: STATIC ESTIMATION RESULTS

\begin{tabular}{|c|c|c|c|c|c|c|}
\hline Variables & Model 1 & Model 2 & Model 3 & Model 4 & Model 5 & Model 6 \\
\hline$\overline{I N C M}$ & $\begin{array}{l}0.740 \text { **** } \\
(13.4)\end{array}$ & $\begin{array}{l}0.690^{* * * *} \\
(10.5)\end{array}$ & $\begin{array}{l}0.742 * * * \\
(13.43)\end{array}$ & $\begin{array}{l}0.696^{* * * *} \\
(10.53)\end{array}$ & $\begin{array}{l}0.954 * * * \\
(24.02)\end{array}$ & $\begin{array}{l}0.894 \text { **** } \\
(16.08)\end{array}$ \\
\hline RP & $\begin{array}{c}0.450 * * * \\
(6.25)\end{array}$ & $\begin{array}{l}0.420 \\
(5.69)\end{array}$ & & & & \\
\hline SP & $\begin{array}{l}1.230 * * * \\
(7.06)\end{array}$ & $\begin{array}{l}1.20 * * * * \\
(6.82)\end{array}$ & & & & \\
\hline EXR & $\begin{array}{l}0.57 * * * \\
(8.10)\end{array}$ & $\begin{array}{l}0.53 \\
(6.80)\end{array}$ & $\begin{array}{l}-1.111 * * * \\
(-5.45)\end{array}$ & $\begin{array}{l}-1.097 * * * \\
(-5.38)\end{array}$ & & \\
\hline ERP & & & $\begin{array}{l}-0.453 * * * \\
(6.26)\end{array}$ & $\begin{array}{l}-0.428 * * * \\
(5.69)\end{array}$ & $\begin{array}{l}-0.550^{* * * *} \\
(7.75)\end{array}$ & $\begin{array}{l}-0.517^{* * * *} \\
(6.98)\end{array}$ \\
\hline ESP & & & $\begin{array}{l}-1.123 * * * \\
(7.04)\end{array}$ & $\begin{array}{l}-1.202 * * * * \\
(6.80)\end{array}$ & $\begin{array}{l}-0.314 * * * \\
(6.43)\end{array}$ & $\begin{array}{l}-0.291 * * * \\
(5.70)\end{array}$ \\
\hline TRC & & $\begin{array}{l}0.043 \\
(1.24)\end{array}$ & & $\begin{array}{l}0.043 \\
(1.24)\end{array}$ & & $\begin{array}{l}0.053 \\
(1.52)\end{array}$ \\
\hline HOP & $\begin{array}{l}0.90 * * * * \\
(19.80)\end{array}$ & $\begin{array}{l}0.830 * * * \\
(10.8)\end{array}$ & $\begin{array}{l}0.904 * * * \\
(19.8)\end{array}$ & $\begin{array}{l}0.829 * * * \\
(10.89)\end{array}$ & $\begin{array}{l}0.873 * * * \\
(19.04)\end{array}$ & $\begin{array}{l}0.780 * * * \\
(10.2)\end{array}$ \\
\hline FOP & $\begin{array}{l}-0.18 * * * \\
(-3.51)\end{array}$ & $\begin{array}{l}-0.18 * * * \\
(-3.68)\end{array}$ & $\begin{array}{l}-0.177 * * * \\
(-3.51)\end{array}$ & $\begin{array}{l}-0.189 * * * \\
(-3.68)\end{array}$ & $\begin{array}{l}-0.121 * * \\
(-2.40)\end{array}$ & $\begin{array}{l}-0.136^{* * *} \\
(-2.66)\end{array}$ \\
\hline Q2 & $\begin{array}{l}0.053 * * * \\
(3.10)\end{array}$ & $\begin{array}{l}0.057 * * * \\
(3.26)\end{array}$ & $\begin{array}{l}0.053 * * * \\
(3.10)\end{array}$ & $\begin{array}{l}0.057 \text { *** } \\
(3.25)\end{array}$ & $\begin{array}{l}0.043 * * \\
(2.50)\end{array}$ & $\begin{array}{l}0.048^{* * * *} \\
(2.72)\end{array}$ \\
\hline Q3 & $\begin{array}{l}0.11 * * * \\
(6.15)\end{array}$ & $\begin{array}{l}0.11 * * * \\
(6.16)\end{array}$ & $\begin{array}{l}0.106^{* * * *} \\
(6.15)\end{array}$ & $\begin{array}{l}0.106^{* * * *} \\
(6.16)\end{array}$ & $\begin{array}{l}0.091 * * * \\
(5.27)\end{array}$ & $\begin{array}{l}0.091 * * * \\
(5.30)\end{array}$ \\
\hline Q4 & $\begin{array}{l}0.007 \\
(0.38)\end{array}$ & $\begin{array}{l}0.023 \\
(1.01)\end{array}$ & $\begin{array}{l}0.007 * * * \\
(.38)\end{array}$ & $\begin{array}{l}0.023 * * * \\
(1.01)\end{array}$ & $\begin{array}{l}-0.002 * * * \\
(-0.11)\end{array}$ & $\begin{array}{l}0.018 \text { *** } \\
(0.77)\end{array}$ \\
\hline TER01 & $\begin{array}{l}0.001 \\
(0.05)\end{array}$ & $\begin{array}{l}-0.002 \\
(0.09)\end{array}$ & $\begin{array}{l}0.001 \\
(.005)\end{array}$ & $\begin{array}{l}-.000 \\
(-0.1)\end{array}$ & $\begin{array}{l}-0.017 \\
(-0.56)\end{array}$ & $\begin{array}{l}-0.021 * * * \\
(-0.74)\end{array}$ \\
\hline SARS03 & $\begin{array}{r}-0.489 * * * \\
(-17.7)\end{array}$ & $\begin{array}{l}-0.478 \text { *** } \\
(-16.5)\end{array}$ & $\begin{array}{l}-0.489 \text { *** } \\
(-17.6)\end{array}$ & $\begin{array}{l}-0.478 * * * \\
(-16.45)\end{array}$ & $\begin{array}{l}-0.495 * * * \\
(-17.67)\end{array}$ & $\begin{array}{l}-0.482 * * * * \\
(-16.37)\end{array}$ \\
\hline GFC08 & $\begin{array}{l}-0.159 * * * \\
(-5.8)\end{array}$ & $\begin{array}{l}-0.160 \text { **** } \\
(-5.88)\end{array}$ & $\begin{array}{l}-0.159 * * * \\
(-5.80)\end{array}$ & $\begin{array}{l}-0.162 * * * * \\
(-5.88)\end{array}$ & $\begin{array}{l}-0.169 * * * \\
(-6.09)\end{array}$ & $\begin{array}{l}-0.172 * * * \\
(-6.19)\end{array}$ \\
\hline Constant & $\begin{array}{l}-3.1 * * * \\
\quad(-6.16)\end{array}$ & $\begin{array}{l}-3.14 * * * \\
(-6.26)\end{array}$ & $\begin{array}{l}-3.086 * * * \\
(-6.17)\end{array}$ & $\begin{array}{l}-3.155^{* * * *} \\
(-6.27)\end{array}$ & $\begin{array}{l}-5.061 * * * \\
(-14.5)\end{array}$ & $\begin{array}{l}-5.111 * * * \\
(-14.58)\end{array}$ \\
\hline HausmanTest & 20.57 & 56.47 & 20.60 & 56.49 & 38.17 & 60.24 \\
\hline Within $\mathrm{R}^{2}$ & 0.786 & 0.787 & 0.786 & 0.787 & 0.781 & 0.781 \\
\hline Between $\mathrm{R}^{2}$ & 0.156 & 0.143 & 0.156 & 0.144 & 0.239 & 0.232 \\
\hline Overall $\mathrm{R}^{2}$ & 0.199 & 0.191 & 0.200 & 0.192 & 0.258 & 0.256 \\
\hline Observation & 1224 & 1224 & 1224 & 1224 & 1224 & 1224 \\
\hline
\end{tabular}

Notes: (1) All variables are in natural logarithmic form. (2) $\Delta$ is first difference operator (3) ***,**, *indicate 1\%,5\%and $10 \%$ significance, respectively. (4) Tourist arrivals is the dependent variable in all models. (5) The t-statistics are reported in parentheses.

Table III displays the static estimation result of six models. We can see that the relative and substitute price has a positive sign in model 1 and model 2 , which is not in accordance with the economic theory, therefore, the explanatory power of those two models are not strong. By contrast, the transport cost variable is not statistically significant in all models, which means it contribute little to the international tourism demand for China. As to R-squares, model 5 which include exchange rate adjusted relative/substitute price seems to better fit the data than others, that is, the price measures with exchange rate standardized relative/substitute price is the most appropriate proxy for tourism price. In the meantime, it is notable that a $1 \%$ increase in effective relative price and effective substitute price is likely to result in a $0.55 \%$ and $0.34 \%$ fall in the number of international numbers for China.

The variable of income, openness, and dummies are found to be significant in the tourism demand models. The elasticities suggest that a rise of $1 \%$ in the income of the tourist is prospected to promote a $0.95 \%$ increase in the international tourists to China. The openness variable shows a totally opposite result between destination country and home country. Specifically, $1 \%$ increase of the openness in China leads to a $0.87 \%$ increase in the tourist arrivals. However, changes in the openness of home countries are negatively influence the tourism demand, and the elasticity indicates that a $1 \%$ increase elicits a $0.12 \%$ fall in the tourist numbers travelling to China. The dummy variables, SARS03 and GFC08, are found negatively significant in the tourism demand.

\section{SUMMARY}

This study aims to investigate the proper proxy for 
tourism price in the tourism demand model during the period of 1996 to 2016. From the empirical results, we can conclude that the effective relative price and effective substitute price are significant determinants in explaining the tourism demand for China, whilst the transport cost is not an important factor. Apart from that, the income, openness and external shocks also exert great influence in international tourism demand.

Considering the practical implications involved, it is of utmost importance for the public and private sectors. Firstly, since most of the tourists are sensitive to the cost of the travelling, we need to keep the pricing strategy more flexible, for example, if the tourism price in competing countries decrease, some positive responses should be taken to keep a competing advantage. At the same time, a relatively stable exchange rate is good for the tourism demand in the long term. It is also important to promote the international trade with other countries, which would greatly boost the development of tourism. Particularly, international tourists tend to visit China in third quarter, thus, it is essential for policy makers and practitioners to launch some promotions to distribute the tourist's flow in high season and try to attract more tourists in low season.

\section{REFERENCES}

[1] World Tourism Organization Tourism Highlights, 2017 Edition

[2] W. Naude and A. Saayman, "Determinants of tourist arrivals in Africa: a panel data regression analysis," Tourism Economics, vol. 11, no. 3, pp. 365-391, 2005.

[3] G. I. Crouch, "The study of international tourism demand: A review of findings," Journal of Travel Research, vol. 33, no. 1, pp. 1223,1994.

[4] H. Song and G. Li, "Tourism demand modelling and forecasting-A review of recent research," Tourism Management, vol. 29, no. 2, pp. 203-220, 2008

[5] K. K. F. Wong, H. Song, S. F. Witt, and D. C. Wu, "Tourism forecasting: To combine or not to combine?" Tourism Management, vol. 28, no. 4, pp. 1068-1078, 2007.

[6] N. Kulendran and K. K. F. Wong, "Modeling seasonality in tourism forecasting," Journal of Travel Research, vol. 44, no. 2, pp. 163-170, 2005 .
[7] H. Song, G. Li, S. Witt, and B. Fei, "Tourism demand modelling and forecasting: how should demand be measured?" Tourism Economics, vol. 16 , no 1 , pp. 63-81, 2010

[8] K. W. H. Tsui, "Does a low-cost carrier lead the domestic tourism demand and growth of New Zealand?," Tourism Management, vol. 60 , pp. 390-403.,2017

[9] K. Weber, "Outdoor adventure tourism: A review of research approaches," Annals of Tourism Research, vol. 28, no. 2, pp. 360377, 2001.

[10] S. Divisekera, "A model of demand for international tourism," Annals of Tourism Research, vol. 30, no. 1, pp. 31-49,2003

[11] D. G. Vita, "The long-run impact of exchange rate regimes on international tourism flows," Tourism Management, vol. 45, no. 5, pp. 226-233, 2014

[12] C. Morley, J. Rosselló, and M. Santana-Gallego, "Gravity models for tourism demand: Theory and use," Annals of Tourism Research, vol. 48, pp. 1-10, 2014.

[13] G. D. Vita and K. S. Kyaw, "Role of the exchange rate in tourism demand," Annals of Tourism Research, vol. 43, pp. 624-627, 2013.

[14] C. Lim, "Review of international tourism demand models,".Annals of Tourism Research, vol. 24, no. 4, pp.835-849, 1997.

[15] C. A. Martin and S. F. Witt, "Substitute prices in models of tourism demand," Annals of Tourism Research, vol. 15, no. 2, pp. 255-268, 1988.

[16] H. Qiu and J. Zhang, "Determinants of Tourist Arrivals and Expenditures in Canada," Journal of Travel Research, vol. 34, no. 2, pp. 43-49,1995

[17] Y. Eilat and L. Einav, "Determinants of international tourism: A three-dimensional panel data analysis," Applied Economics, vol. 36, no.12, pp.1315-1327,2004

[18] J. Shan and K. Wilson, "Causality between trade and tourism: Empirical evidence from China," Applied Economics Letters, vol. 8, no. 4, pp. $279-283,2001$

[19] K. N. Wong and T. C. Tang, "Tourism and openness to trade in Singapore: Evidence using aggregate and country-level data," Tourism Economics, vol.16, no. 4, pp. 965-980, 2010.

[20] G. I. Crouch, "The study of international tourism demand: A review of findings," Journal of Travel Research, vol. 33, no. 1, pp.12-23, 1994

[21] B. Peng, H. Song, and G. I. Crouch, "A meta-analysis of international tourism demand forecasting and implications for practice," Tourism Management, vol. 45, pp. 181-193.

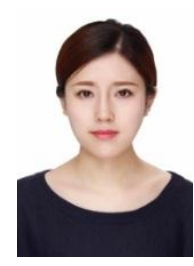

Qiong Zhang is a Ph.D. in the tourism management at Sichuan University; Her primary research interests include international tourism demand and cultural tourism. 